\title{
Correlation between Anatomy and Root Canal Topography of First Maxillary Premolar on Kosovar Population
}

\author{
Ferit Koçani, Blerim Kamberi, Edmond Dragusha, Tringa Kelmendi, Zana Sejfija \\ Conservative Dentistry and Endodontics, Faculty of Medicine/Stomatology, University of Prishtina "Hasan \\ Prishtina", Prishtina, Kosovo \\ Email: ferit.kocani@uni-pr.edu
}

Received 17 May 2014; revised 25 June 2014; accepted 13 July 2014

Copyright (C) 2014 by authors and Scientific Research Publishing Inc.

This work is licensed under the Creative Commons Attribution International License (CC BY).

http://creativecommons.org/licenses/by/4.0/

(c) (i) Open Access

\section{Abstract}

Aim: In this in vitro study the variation of root anatomy and canal system of the first human maxillary premolar was evaluated. Materials and Methods: Two hundred and twenty one maxillary first premolars (\#221 teeth) were examined. All of the teeth were identified using the accepted criteria of Woelfel as maxillary first premolars. Selected teeth are analyzed using operating microscope (OP) and computed dental radiography (CDR). Results: There was a higher incidence of two-roots form $70.14 \%(n=155), 21.72 \%(n=48)$ had one root, and $8.14 \%(n=18)$ had three roots. In the two-root category, $16.29 \%(n=36)$ had bifurcation on apical third, $21.72 \%(n=48)$ had bifurcation on middle third, and $32.13 \%(n=71)$ had bifurcation on cervical third. The examination of root canal systems of the teeth was based on Vertucci's classification type of canal: $64.58 \%$ (\#31) of the cases had type IV (2-2-2), $25.00 \%$ (\#12) type II (2-2-1), 8.33\% (\#4) type I (1-1-1), and 2.09\% (\#1) type III (1-2-1). Conclusion: This study showed a high incidence of two-rooted maxillary first premolars collected from different regions in Kosovo. Internal root canal system morphology reflects the external root anatomy. Furthermore, there is correlation between the shape of the outer surface of the root and the shape of the root canal. The cases with one root of the maxillary first premolar with a deep depression on the mesial side contain a double root canal system more often than a single canal.

\section{Keywords}

Maxilary First Premolar, Root Anatomy, Root Canal System

\section{Introduction}

Root Canal Therapy (RCT) depends upon complete and accurate biomechanical preparation followed by a 3D

How to cite this paper: Koçani, F., Kamberi, B., Dragusha, E., Kelmendi, T. and Sejfija, Z. (2014) Correlation between Anatomy and Root Canal Topography of First Maxillary Premolar on Kosovar Population. Open Journal of Stomatology, 4, 332339. http://dx.doi.org/10.4236/ojst.2014.47046 
obturation of the root canal system in the absence of injury to periapical tissues [1]. The failure of these treatments, is very often as a result of morphological variation, except the main root canal there can also present the accessory and supplementary (lateral ) canals and this is trait for every tooth [2] [3]. The internal anatomy of the maxillary first premolars is particularly complex due to their variation in number of roots and canal configuration [4]. Recent research has reported different incidence of first maxillary premolars. One root varied from $15.5 \%$ to $60 \%$ [5]-[9], while incidence with two roots varied from $50.6 \%$ to $72 \%$; and with three roots $0 \%$ to $6 \%$ [6]-[8] [10] [11].

In cases with one root, incidence of first maxillary premolars with a single canal varies from 33.9\% [12] to 20.4\% [13], Pecora observed an incidence 17.1\% [4], Kartal 8,7\% [11], Vertucci found 8.0\% [6], 3.3\% found Lama [7], Lipski 2.1\% [5], and Chaparro 1.4\% [14].

The presence of two canals is high and in discrepancy with used method, number of teeth and geographic location of population (ethnic background) and great anatomical variation of first maxillary premolar. Chaparro [14] found 95.3\%, Kartal [11] 89.6\%, Lipski found 88.6\% [5], 87.3\% Xi-Li Weng [15], 87.1\% Nganga [16], Vertucci 87.0\% [6], Pecora observed an incidence 80.4\% [4], 79.7\% Lama [7], and Pineda 65.6\% [12]. Low incidence with three canals varies from $0 \%-3 \%$ [4] [9] [17]-[19].

The aim of this in vitro study was to examine the root anatomy and canal morphology of the first human maxillary premolar with completely formed root apices: the length of tooth, the number and correlation between roots, the direction of the root curvature, the external surface of the roots, and root canal morphology (root canal system).

\section{Materials and Methods}

Two hundred twenty one first maxillary premolars (\#221 teeth) were examined which had previously been extracted because of periodontal disease, or orthodontic reasons, and without knowing the history, collected by students from different regions of Kosovo (Kosovo Albanians). All of the teeth were absolutely identified by two independent observers using the accepted criteria of Woelfel [20] as maxillary first premolars, Figure 1. They were washed after extraction and stored in a $10 \%$ formalin solution until the collection was completed. Each tooth was cleaned of any adherent soft tissues, bone fragments and calculus by scaling and polishing. Teeth were washed under running tap water and dried using a $97 \%$ ethanol solution. In this research were carefully observed and recorded: the length of tooth, number of roots and its correlation, the direction of the root curvature, the external surface of the roots, and the internal morphology of root canal system.

The length of these teeth were measured by micrometer (Westec, India), from buccal cusp tip to the root apex on the tooth with single root, and from the buccal and palatal cusp tip to the apex of buccal and palatal root. Visual inspection of the root morphology was made and the findings were recorded. The teeth were classified into groups according to number of the roots and incidence of fusion, the direction of the root curvature, and the external surface of the roots. Longitudinal depression (mesial and distal) on root was measured according to visualization from cement-enamel junction to apex: smooth, convex, slight and deep depression.

The internal morphology of root canal system was studied as followed; teeth are cut at cement-enamel junction (CEJ) with turbine (W\&H, Austria) with fissure burs nr.4 (Meisinger, Germany) under water, standard access was made in each tooth until the pulpal chamber. The teeth were stored in $5.25 \%$ sodium hypochlorite solution for two days to remove pulpal tissue. Teeth were then washed in tap water for 2 hours. Operating microscope (OP) has been made for apparent entry into the root canals, under $\times 250$ magnification. K file \#6, \#08 or \#10 was inserted into canal, until the end of the root canal. Subsequently was making CDR (Computed Dental Radiography, Schick Technology USA) radiography, visualizing the internal topography of the root canal system.

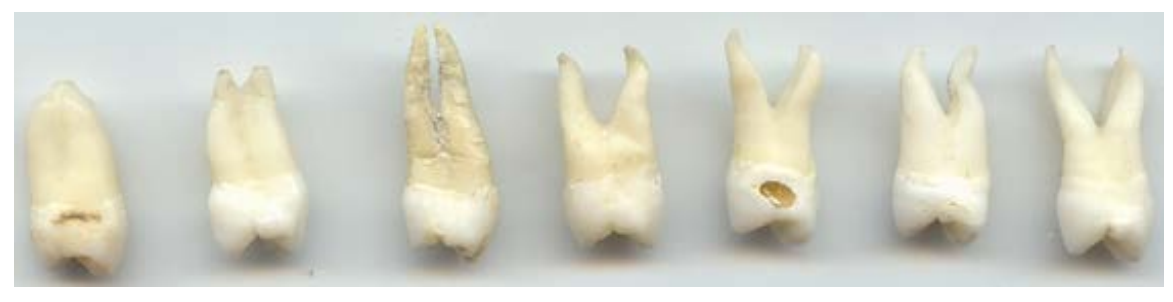

Figure 1. Collection of variation of first maxillary premolar. 
Root was then cut toward longitudinal on buccal/lingual direction until the instrument has been made visible on canal. $\mathrm{K}$ file is removed from the canal, under operating microscope $\times 250$ magnification was analyzed extension of each root canal. The root canal systems were classified according to the classification of Vertucci [6].

\section{Results}

On 221 maxillary first premolar teeth, 70.14\% $(\mathrm{n}=155)$ had two roots, 21.72\% $(\mathrm{n}=48)$ had one root, and 8.14\% ( $\mathrm{n}=18)$ had three roots, Table 1.

One hundred and fifty five (70.14\%) of the specimens with two roots, Table 2, of which $16.29 \%(n=36)$ had bifurcation on apical third, 21.72\% $(n=48)$ had bifurcation on middle third, and 32.13\% $(n=71)$ had bifurcation on cervical third.

The length of the maxillary first premolar, Table 3, with one root was $21.4 \mathrm{~mm}$ (range 26.3 - $16.7 \mathrm{~mm}$ ). On the samples with two roots, average of buccal root length has $20.8 \mathrm{~mm}$ (range $24.8-17.3 \mathrm{~mm}$ ) and a palatal root length of 21.0 (range 25.2 - $21.2 \mathrm{~mm}$ ). First maxillary premolar with three roots, the length average of MB root has $21.7 \mathrm{~mm}$ (range 25.8 - $19.9 \mathrm{~mm}$ ), DB root average $22.0 \mathrm{~mm}$ (range 24.9 - $20.6 \mathrm{~mm}$ ) and palatal root 21.3 $\mathrm{mm}$ (range $27.8-17.4 \mathrm{~mm}$ ).

The roots of maxillary first premolar viewed from mesial and distal aspect have root depressions of varying depths, only with an obvious concavity or depression on the mesial surface of crown and this depression continues on to the root, Table 4. The teeth with fused root were found to have a deep depression on the mesial side (74.8\%), and the distal side have $48.1 \%$ deep concavity. On the distal root surface, the root is convex (7.1\%) then smooths (5.2\%), and with slight depression were found on $39.6 \%$.

Direction of root curvature, Table 5, on the cases with one root toward distal $73.9 \%$, and straight $18.6 \%$. On the premolar with two roots: the buccal root toward distal on $38.3 \%$, toward palatal $26.8 \%$, and root was straight $19.9 \%$. On palatal root were observed a distal curvature on $41.9 \%$, toward buccal $24.9 \%$, straight on $21.1 \%$, and had "S" shape on $8.8 \%$. The teeth with three roots (8.14\%), MB root toward mesial on $41.8 \%$, DB root toward mesial $48.8 \%$, palatal root toward palatal on $56.9 \%$, and straight $41.0 \%$.

Distribution of number of canals on single rooted first premolar, Table 6: with one canal was found 8.33\%,

Table 1. Frequency distribution of roots of first maxillary premolar.

\begin{tabular}{cccc}
\hline Number of teeth & One root & Two roots & Three roots \\
\hline 221 & (48) $21.72 \%$ & (155) $70.14 \%$ & (18) $8.14 \%$ \\
\hline
\end{tabular}

Table 2. Classification of roots of the first maxillary premolar.

\begin{tabular}{|c|c|c|c|}
\hline & & Nr. of teeth & $\%$ \\
\hline 1 & Single root & 48 & 21.72 \\
\hline 2.a & Two roots, bifurcation on apical third & 36 & 16.29 \\
\hline 2.b & Two roots, bifurcation on middle third & 48 & 21.72 \\
\hline 2.c & Two roots, bifurcation on cervical third & 71 & 32.13 \\
\hline \multirow[t]{2}{*}{3} & Three root & 18 & 8.14 \\
\hline & Total & 221 & 100 \\
\hline
\end{tabular}

Table 3. The length of the maxillary first premolar measured from cusp tip to the apex Overall length (mm).

\begin{tabular}{|c|c|c|c|c|c|c|c|c|c|c|c|c|c|c|c|c|c|}
\hline \multicolumn{3}{|c|}{ One root } & \multicolumn{6}{|c|}{ Two roots } & \multicolumn{9}{|c|}{ Three roots } \\
\hline & & & & Buccal & & & Palatal & & & M.B. & & & D.B & & & Palata & \\
\hline Av & Max & Min & Av & Max & Min & Av & $\operatorname{Max}$ & Min & Av & Max & Min & Av & Max & Min & Av & Max & Min. \\
\hline 21.4 & 26.3 & 16.7 & 20.8 & 24.8 & 17.3 & 21.0 & 25.2 & 21.2 & 21.7 & 25.8 & 19.9 & 22.9 & 24.9 & 20.6 & 21.3 & 27.8 & 17.4 \\
\hline
\end{tabular}


with two canals $91.67 \%$.

According to Vertucci classification type of canal, Table 7 \& Figure 2, 64.58\% (\#31) of the cases had type IV (2-2-2), 25.00\% (\#12) type II (2-1), 8.33\% (\#4) type I (1) and 2.09\% (\#1) type III (1-2-1).

\section{Discussion}

A detailed understanding of the complexity of root canal systems is imperative to ensure successful endodontic therapy. On the other hand, there is correlation between the shape of the outer surface of the root and the shape

\begin{tabular}{|ccc|}
\hline Table 4. Root depression of proximal surface. & \\
\hline & Mesial & Distal \\
\hline Smooth & 1.6 & 7.0 \\
Convex & - & 12.1 \\
Slight depression & 23.6 & 51.3 \\
Deep depression & 74.8 & 29.6 \\
Total & $\mathbf{1 0 0 . 0}$ & $\mathbf{1 0 0 . 0}$ \\
\hline
\end{tabular}

Table 5. Direction of root curvature \%.

\begin{tabular}{|c|c|c|c|c|c|c|}
\hline \multirow[b]{2}{*}{ Direction of curvature } & \multirow{2}{*}{$\begin{array}{c}1 \text { root } \\
-\end{array}$} & \multicolumn{2}{|c|}{2 roots } & \multicolumn{3}{|c|}{3 roots } \\
\hline & & B & $\mathrm{P}$ & $\mathrm{MB}$ & DB & $\mathrm{P}$ \\
\hline Straight & 18.6 & 19.9 & 21.1 & 11.8 & 16.5 & 41 \\
\hline Toward Palatal & 1 & 26.8 & 2.3 & 0.5 & 3.2 & 56.9 \\
\hline Toward Buccal & 1.2 & 2.3 & 24.9 & - & 0.6 & - \\
\hline Toward Mesial & 0.5 & 0.7 & 1 & 41.8 & 48.8 & - \\
\hline Toward Distal & 73.9 & 38.3 & 41.9 & 27.4 & 29.3 & 2.1 \\
\hline “S”curve & 4.8 & 12 & 8.8 & 18.5 & 1.6 & - \\
\hline Total & 100 & 100 & 100 & 100 & 100 & 100 \\
\hline
\end{tabular}

Table 6. Number of canals (\%) on single rooted first maxillary premolar.

\begin{tabular}{crrr}
\hline Number of teeth & One canal & Two canals & Three canals \\
\hline 48 & $8.33 \%$ & $91.67 \%$ & $0 \%$ \\
\hline
\end{tabular}

Table 7. Number of canals (\%) on each root and the type.

\begin{tabular}{|c|c|c|c|c|c|c|}
\hline \multirow[t]{2}{*}{ One root } & \multicolumn{2}{|c|}{ Two rooted (\#155) } & \multicolumn{3}{|c|}{ Three rooted (\#18) } & \multirow{2}{*}{$\begin{array}{l}\text { Conf } \\
\text { Type }\end{array}$} \\
\hline & $\mathbf{B}$ & $\mathbf{P}$ & MB & DB & $\mathbf{P}$ & \\
\hline $4(8.33 \%)$ & (155) $100 \%$ & (155) $100 \%$ & (18) $100 \%$ & (18) $100 \%$ & (18) $100 \%$ & $I^{*}$ \\
\hline $12(25.00 \%)$ & 0 & 0 & 0 & 0 & 0 & $\mathrm{II}^{*}$ \\
\hline $1(2.09 \%)$ & 0 & 0 & 0 & 0 & 0 & III* \\
\hline 31 (64.58\%) & 0 & 0 & 0 & 0 & 0 & $\mathrm{IV}^{*}$ \\
\hline
\end{tabular}

I* a single canal extending from the pulp chamber to the apex of the root; II* two separate root canals leave the pulp chamber and join short of the apex to form one canal; III* one orifices, two separated canals leave the pulp chamber and join short of the apex to form one canal; $\mathbf{I V}^{*}$ two separate canals in one root. 


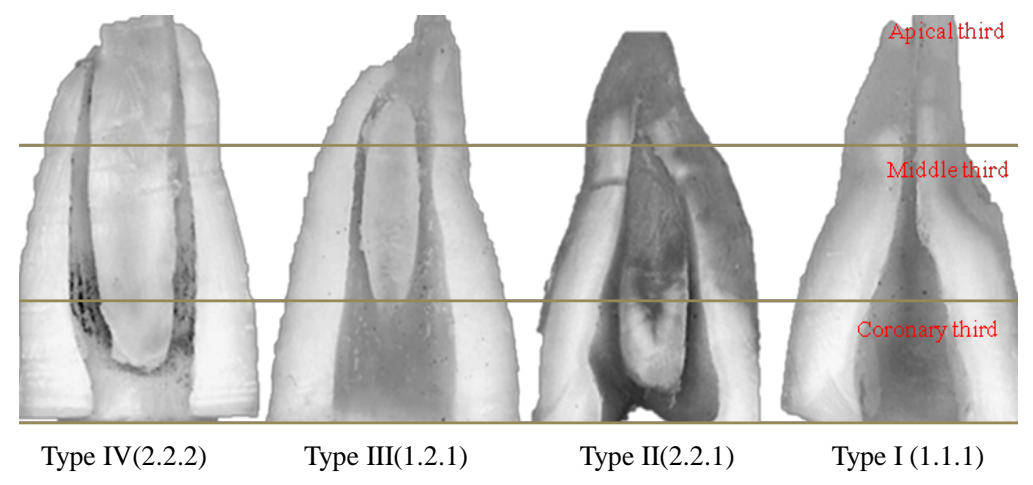

Figure 2. Type of root canal on first maxillary premolar with one root.

of the root canal [4]. There is a wide range of variation in the literature with respect to frequency of occurrence of the number of canals in each root, the number of roots and incidence of fusion [5]-[14]. Furthermore, such variations affect clinical practice, and clinicians should be aware of the geographic/ethnic background and individual differences in tooth morphology.

In 1969 Weine [21] provided the first clinical classification of more than one canal system in a single root and used the mesiobuccal root of the maxillary first molar as the type specimen. Pineda [12] and Vertucci [22] further developed a system for canal anatomy classification for any tooth that has a broad buccolingual diameter and may be more applicable for use in laboratory studies.

Several studies and methods have been employed and showed differences in root and canal morphology of the first maxillary premolar. Researches have also proved correlation between the shape of the outer surface of root and the shape of the root canal [4].

These methods include decalcification of the teeth and dye injection [22], with India Ink [23]) or Hematoxylin, a new modified root canal staining technique [15], [24] by immersion ink without preparing access cavities and then put into hyperbaric oxygen chamber, In vivo [19]) and in vitro radiographic studies [25]), sectioning of the teeth [26]), and Computed Tomography [27] [28] have been used to study the anatomy of pulp space.

In the present study, $21.72 \%$ of the first maxillary premolar teeth had one root. This value is higher than reported, Table 8, in the Polish population [5] but, lower than reported from other populations [2]-[9], Vertucci 26\% [2], Loh 49.4\% [8], and Walker 60\% [9].

A prevalence of $70.14 \%$ of two-rooted specimens was recorded in the present study, which is higher than values: 40.0\% [9] in Chinese population, 41.7\% [4] Brazilian, 56.7\% [14] Spanish, 54.6\% [12] Mexicans, and 56.5\% [6] white Americans.

On the other hand, Lipski [5] recorded 75.3\% of two-rooted specimens in the Polish population, while Charles Mugisha Rwenyonyi Ugandan recorded 73.3\% [13], and 80.9\% Atieh in the Saudi population [29].

In the present study with two roots, 71 teeth (32.13\%) had bifurcation on cervical third, 48 (21.72\%) on middle third, and 36 (16.29\%) on apical third.

This value was compared to 32.1\% of the teeth in the Singaporeans [8], 26\% in the Polish Lipski found 26\% with fused roots (for more than their length) [5], Atieh 36.2\% in the Saudis population [29].

The three-rooted maxillary first premolar had the lowest incidence in all studies and ranged between 0\% Walker [9] Chinese and Rwenyonyi [13] Ugandans, 1.2\% Atieh [29] Saudis, Vertucci \& Gegauff 4.0\% [6], and Lipski 9.2\% [5]. In our research we found 8.14\% with three roots.

Slightly differences between palatal shortly $(0.2 \mathrm{~mm})$ than the buccal roots, is in accordance with other authors [20].

Single rooted first premolar was curved toward distal 73.9\%, Pecora [4] found of 79.9\%). Two rooted premolar, the palatal root was straight 21.1\%, Pecora [4] found 24\%), and curved toward buccal 24.9\%, Pecora [4] 26\%). The samples with three roots, root curved toward mesial dominant DB (disto-buccal) $48.8 \%$ and MB (mesio-buccal) $41.8 \%$. Palatal roots curvature toward lingual 56.9\%.

The mesial side root concavities, with obvious depression on the mesial surface of the crown continues on to the root, were deeper (74.8\%) than those on the distal side, Pecora [4] found 72.4\%)

The most common canal configuration for the single root maxillary first premolar is Vertucci type IV (two 
Table 8. Comparison of root numbers in maxillary first premolars in previous studies and those in the current study.

\begin{tabular}{|c|c|c|c|c|c|}
\hline Author (year) & Origin & No. of teeth & One root & Two roots & Three roots \\
\hline Pineda \& Kuttler (1972) [12] & Mexicans & 259 & 43.0 & 54.6 & 2.4 \\
\hline Carns \& Skidmore (1973) [10] & White Americans & 100 & 22.0 & 72.0 & 6.0 \\
\hline Vertucci \& Gegayff (1979) [6] & White Americans & 400 & 39.5 & 56.5 & 4.0 \\
\hline Walker (1987) [9] & Chinese & 100 & 60.0 & 40.0 & 0 \\
\hline Pecora et al. (1992) [4] & Brazilians & 240 & 55.8 & 41.7 & 2.5 \\
\hline Loh (1998) [8] & Singaporeans & 957 & 49.4 & 50.6 & 0 \\
\hline Chaparro et al. (1999) [14] & Spanish & 150 & 40.0 & 56.7 & 3.3 \\
\hline Lipski et al. (2003) [5] & Polish & 142 & 15.5 & 75.3 & 9.2 \\
\hline Awawdeh et al. (2008) [7] & Jordanians & 600 & 30.8 & 68.4 & 0.8 \\
\hline Atieh (2008) [29] & Saudis & 246 & 17.9 & 80.9 & 1.2 \\
\hline Özcan et al. (2012) [36] & Turkish & 653 & 45.2 & 53.7 & 1.1 \\
\hline Rwenyonyi et al. (2011) [13] & Ugandans & 202 & 26.7 & 73.3 & 0 \\
\hline Elkady et al. (2013) [35] & Saudis subpopulation & 120 & 28.3 & 71.7 & 0 \\
\hline The present study & Kosovar & 221 & 21.72 & 70.14 & 8.14 \\
\hline
\end{tabular}

separate canals in one root) with 64.58\%, type II (two separate root canals leave the pulp chamber and join short of the apex to form one canal) $25.00 \%$, type I (a single canal extending from the pulp chamber to the apex of the root) with $8.33 \%$, and type III (one orifices, two separated canals leave the pulp chamber and join short of the apex to form one canal).

The first maxillary premolars with three roots had three canals mesiobuccal (MB), distobuccal (DB), and palatal. In this case with a canal and root disposition so similar to that of adjacent first molars that they are sometimes called small molars or "ridiculous" [30]-[36].

\section{Conclusions}

Major conclusions can be drawn from this study as follows:

Most maxillary first premolar teeth collected from different region of Kosovo showed a higher prevalence of two-root morphology (70.14\%), with one root (21.72\%), and with three roots $8.14 \%$.

The majority of first maxillary premolar teeth with single root have a distal curvature (root toward distal 73.9\%). Buccal (38.3\%) and palatal (41.9\%) roots toward distal on two rooted premolar.

The curvature of mesiobuccal (MB) root toward mesial 41.8\%, distobuccal (DB) 48.8\%, the palatal toward lingual $56.9 \%$ on the first premolar with three roots. "S" curve predominant $(18.5 \%)$ on MB roots in the cases with three roots.

Prevalence of deep longitudinal depression on proximal surface with one root was observed on mesial root surface of $74.8 \%$ and slight on $48.1 \%$ of the distal root surface.

In the cases with one root, there is a correlation between outer shape of root (the mesial side concavity with obvious longitudinal depression, 74.8\%) and internal topography of root canal system (contains a double root canal system more often than single canal).

On single rooted premolar there found one canal of 8.33\% (Type I), two canals 91.1\% (Type IV = 64.58\%, Type III = 2.09\% and Type II = 25.00\%).

\section{References}

[1] Ricucci, D. and Langeland, K. (1998) Apical Limit of Root Canal Instrumentation and Obturation, Part 2. Histological Study. International Endodontic Journal, 31, 394-409. http://dx.doi.org/10.1046/j.1365-2591.1998.00183.x 
[2] Vertucci, F.J. (2005) Root Canal Morphology and Its Relationship to Endodontic Procedures. Endodontic Topics, 10, 3-29. http://dx.doi.org/10.1111/j.1601-1546.2005.00129.x

[3] Sutalo, J. and Njemirovskij, V. (1980) Morphologic Characteristics of Root Canals in Upper and Lower Premolars. Acta Stomatologica Croatica, 14, 23-28.

[4] Pecora, J.D., Saquy, P.C., Sousa Neto, M.D. and Woelfel, J.B. (1992) Root Form and Canal Anatomy of Maxillary First Premolars. Brazilian Dental Journal, 2, 87-94.

[5] Lipski, M., Woźniak, K., Lagocka, R. and Tomasik, M. (2003) Root and Canal Morphology of the First Human Maxillary Premolar. Durham Anthropology Journal, 12, 2-3.

[6] Vertucci, F.J. and Gegauff, A. (1979) Root Canal Morphology of the Maxillary First Premolars. Journal of American Dental Association, 99, 194-198.

[7] Awawdeh, L., Abdullah, H. and Al-Qudah, A. (2008) Root Form and Canal Morphology of Jordanian Maxillary First Premolars. Journal of Endodontics, 34, 956-961. http://dx.doi.org/10.1016/j.joen.2008.04.013

[8] Loh, H.S. (1998) Root Morphology of the Maxillary First Premolar in Singaporeans. Australian Dental Journal, 43, 399-402. http://dx.doi.org/10.1111/j.1834-7819.1998.tb00199.x

[9] Walker, R.T. (1987) Root Form and Canal Anatomy of Maxillary First Premolars in a Southern Chinese Population. Dental Traumatology, 3, 130-134. http://dx.doi.org/10.1111/j.1600-9657.1987.tb00614.x

[10] Carns, E.J. and Skidmore, A.E. (1973) Configurations and Deviations of Root Canals of Maxillary First Premolars. Oral Surgery, Oral Medicine \& Oral Pathology, 36, 880-886. http://dx.doi.org/10.1016/0030-4220(73)90340-X

[11] Kartal, N., Ozcelik, B. and Cimilli, H. (1998) Root Canal Morphology of Maxillary Premolars. Journal of Endodontics, 24, 417-419. http://dx.doi.org/10.1016/S0099-2399(98)80024-1

[12] Pineda, F. and Kuttler, Y. (1972) Mesiodistal and Buccolingual Rentgenographic Investigation of 7,275 Root Canals. Oral Surgery, Oral Medicine \& Oral Pathology, 33, 101-110. http://dx.doi.org/10.1016/0030-4220(72)90214-9

[13] Rwenyonyi, C.M., Kutesa, A., Muwazi, L. and Buwembo, W. (2011) Root and Canal Morphology of Maxillary First Premolar Teeth in a Ugandan Population. Open Journal of Stomatology, 1, 7-11. http://dx.doi:10.4236/ojst.2011.11002

[14] Chaparro, A.J., Segura, J.J., Guerrero, E., Jimenez-Rubio, A., Murillo, C. and Feito, J.J. (1999) Number of Roots and Canals in Maxillary First Premolars: Study of an Andalusian Population. Dental Traumatology, 15, 65-67. http://dx.doi.org/10.1111/j.1600-9657.1999.tb00755.x

[15] Weng, X.-L., Yu, S.-B., Zhao, S.-L., Wang, H.-G., Mu, T., Tang, R.-Y. and Zhou, X.-D. (2009) Root Canal Morphology of Permanent Maxillary Teeth in the Han Nationality in Chinese Guanzhong Area: A New Modified Root Canal Staining Technique. Journal of Endodontics, 35, 651-656. http://dx.doi.org/10.1016/j.joen.2009.02.010

[16] Ng'ang'a, R.N., Masiga, M.A. and Maina, S.W. (2010) Internal Root Morphology of the Maxillary First Premolars in Kenyans of African Descent. East African Medical Journal, 87, 20-24.

[17] Okumura, T. (1927) Anatomy of the Root Canals. Journal of American Dental Association, 14, 632-636.

[18] Green, D. (1973) Double Root Canal in Single Roots. Oral Surgery, Oral Medicine \& Oral Pathology, 35, $689-696$. http://dx.doi.org/10.1016/0030-4220(73)90037-6

[19] Bellizzi, R. and Hartwell, G. (1985) Radiographic Evaluation of Root Canal Anatomy of in Vivo Endodontically Treated Maxillary Premolars. Journal of Endodontics, 11, 37-39. http://dx.doi.org/10.1016/S0099-2399(85)80104-7

[20] Woelfel, J.B. (1990) Dental Anatomy: Its Relevance to Dentistry. 4th Edition, Lea and Febiger, Philadelphia, 81-103.

[21] Weine, F.S., Healey, H.J., Gerstein, H. and Evanson, L. (1969) Canal Configuration in the Mesiobuccal Root of the Maxillary First Molar and Its Endodontic Significance. Oral Surgery, Oral Medicine \& Oral Pathology, 28, 419-425. http://dx.doi.org/10.1016/0030-4220(69)90237-0

[22] Vertucci, F.J. (1984) Root Canal Anatomy of the Human Permanent Teeth. Oral Surgery, Oral Medicine \& Oral Pathology, 58, 589-599. http://dx.doi.org/10.1016/0030-4220(84)90085-9

[23] Gulabivala, K., Aung, T.H., Alavi, A. and Ng, Y.-L. (2001) Root and Canal Morphology of Burmese Mandibular Molars. International Endodontic Journal, 34, 359-370. http://dx.doi.org/10.1046/j.1365-2591.2001.00399.x

[24] Neelakantan, P., Subbarao, C., Ahuja, R. and Subbarao, C.V. (2011) Root and Canal Morphology of Indian Maxillary Premolars by a Modified Root Canal Staining Technique. Odontology, 99, 18-21. http://dx.doi.org/10.1007/s10266-010-0137-0

[25] Gonzalez-Plata, R.R. and Gonzalez-Plata, E.W. (2003) Conventional and Surgical Treatment of a Two-Rooted Maxillary Central Incisor. Journal of Endodontics, 29, 422-424. http://dx.doi.org/10.1097/00004770-200306000-00011

[26] Weine, F.S., Hayami, S., Hata, G. and Toda, T. (1999) Canal Configuration of the Mesiobuccal Root of the Maxillary First Molar of a Japanese Sub-Population. International Endodontic Journal, 32, 79-87. http://dx.doi.org/10.1046/j.1365-2591.1999.00186.x 
[27] Deepak, Sh. and Meetu, M. (2011) A Computed Tomographic Study of Canal Variations in Maxillary \& Mandibular first Premolar Teeth in Jaipur Population-An in Vitro Study. People’s Journal of Scientific Research, 4, 1-5.

[28] Neelakantan, P., Subbarao, C. and Subbarao, C.V. (2010) Comparative Evaluation of Modified Canal Staining and Clearing Technique, Cone-Beam Computed Tomography, Peripheral Quantitative Computed Tomography, Spiral Computed Tomography, and Plain and Contrast Medium-Enhanced Digital Radiography in Studying Root Canal Morphology. Journal of Endodontics, 36, 1547-1551. http://dx.doi.org/10/1016/j.joen.2010.05.008

[29] Atieh, M.A. (2008) Root and Canal Morphology of Maxillary First Premolars in a Saudi Population. Journal of Contemporary Dental Practice, 9, 46-53.

[30] Alavi, A.M., Opasanon, A., Ng, Y.L. and Gulabivala, K. (2002) Root and Canal Morphology of Thai Maxillary Molars. International Endodontic Journal, 35, 478-485. http://dx.doi.org/10.1046/j.1365-2591.2002.00511.X

[31] Hess, W. (1925) The Anatomy of the Root-Canals of the Teeth of the Permanent Dentition, Part 1. William Wood and Co., New York.

[32] Sert, S. and Bayirli, G.S. (2004) Evaluation of the Root Canal Configurations of the Mandibular and Maxillary Permanent Teeth by Gender in the Turkish Population. Journal of Endodontics, 30, 391-398. http://dx.doi.org/10.1097/00004770-200406000-00004

[33] Slowey, R.R. (1974) Radiographic Aids in the Detection of Extra Root Canals. Oral Surgery, Oral Medicine \& Oral Pathology, 37, 762-772. http://dx.doi.org/10.1016/0030-4220(74)90142-X

[34] Kamberi, B., Kocani, F., Ahmetaj, M. and Mrasori, S.H. (2009) Variations in the Number of Roots and Canals in the 1st Maxillar Premolar. Proceeding European Federation Conservative Dentistry Conseuro Confererence, Seville, Spain. Clinical Oral Investigation, 13, 49-118. http://dx.doi.org/10.1007/s00784-009-0248-6

[35] Elkady, A.M. and Allouba, K. (2013) Cone Beam Computed Tomographic Analysis of Root and Canal Morphology of Maxillary Premolars in Saudi Subpopulation. Egyptian Dental Journal, 59, 3419-3429.

[36] Özcan, E., Çolak, H. and Hamidi, M.M. (2012) Root and Canal Morphology of Maxillary First Premolars in a Turkish Population. Journal of Dental Sciences, 7, 390-394. http://dx.doi.org/10.1016/j.jds.2012.09.003 
Scientific Research Publishing (SCIRP) is one of the largest Open Access journal publishers. It is currently publishing more than 200 open access, online, peer-reviewed journals covering a wide range of academic disciplines. SCIRP serves the worldwide academic communities and contributes to the progress and application of science with its publication.

Other selected journals from SCIRP are listed as below. Submit your manuscript to us via either submit@scirp.org or Online Submission Portal.
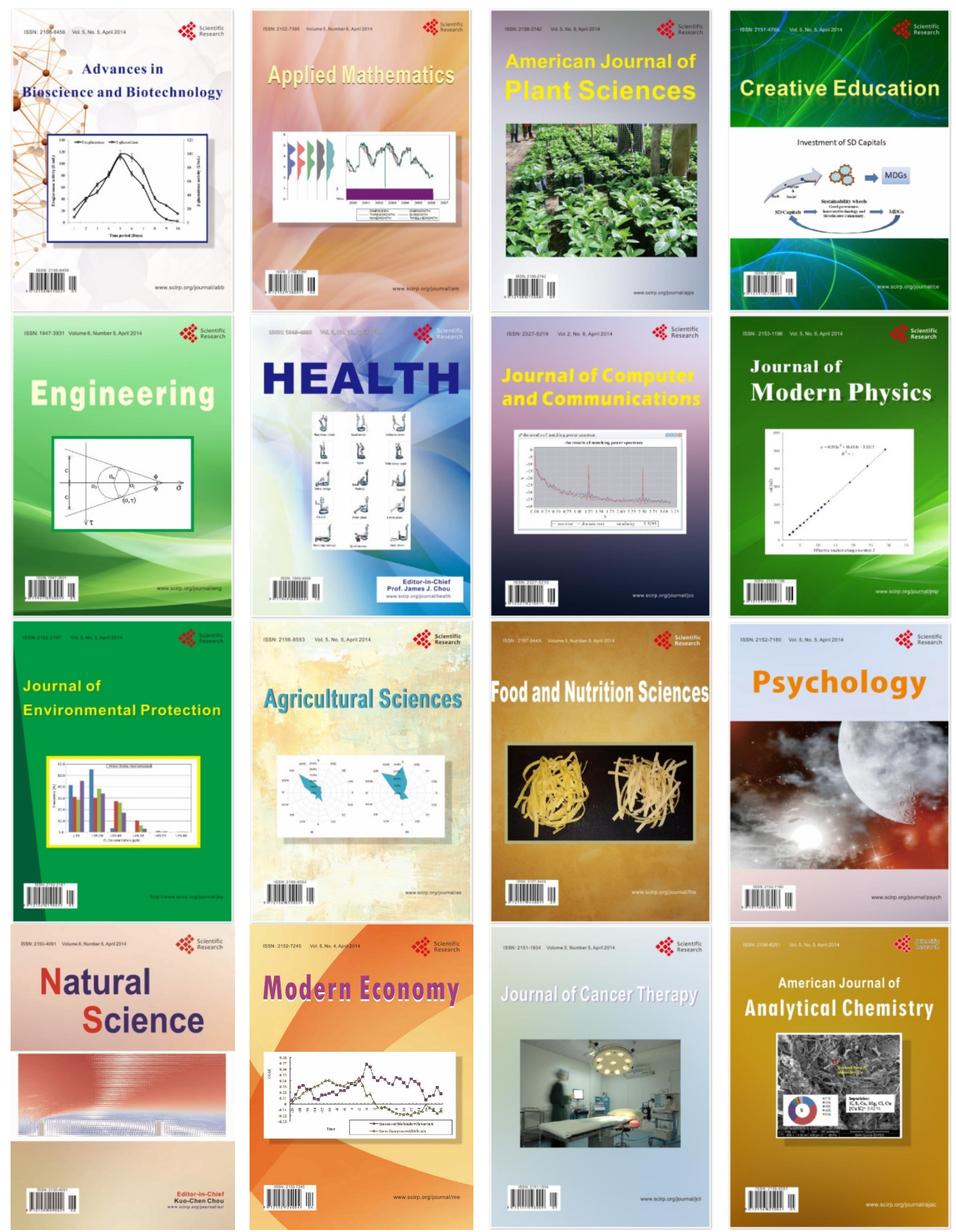